\title{
THE IMPACT OF HIGH - POWER ELECTROMAGNETIC PULSES ON THE SURFACE STATE AND TECHNOLOGICAL PROPERTIES OF THE CALCIFEROUS MINERALS
}

\author{
V.A. Chanturiya', I.Zh. Bunin'1, M.V. Ryazantseva ${ }^{1 \#}$ \\ 1/nstitute of Comprehensive Exploitation of Mineral Resources Russian Academy of Sciences \\ named after academician N.V. Mel'nikov, Moscow, Russia
}

(Received: September 30, 2019; Accepted: November 14, 2019)

\begin{abstract}
The modification of structural chemical properties of natural fluorite, scheelite and calcite under the impact of high-power electromagnetic pulses (HPEMP-treatment) were studied with help of adsorption of acid-base indicators. It was determined that the HPEMP-treatment during of 30 seconds $\left(3 \times 10^{3}\right.$ pulses) resulted in the intensification of fluorite surface 'electron-donating ability and acceptor properties of calcite and scheelite surfaces.

Single mineral flotation tests has allowed to determine that treatment by high-power electromagnetic pulses resulted in the improvement of the calciferous minerals floatability. The rising of the scheelite recovery was $10-12 \%$, for fluorite it was $5-6 \%$, for calcite $7-8 \%$.
\end{abstract}

Key words: Calcite; Fluorite; Scheelite; Floatability; High-power electromagnetic pulses.

\section{Introduction}

A detailed study of the relationship between the parameters of the treatment by high-power electromagnetic pulses (HPEMP-treatment) and the surface properties of calciferous minerals is of high relevance for the development and refinement of the existing understanding of the processes involved in the interaction between strong electromagnetic fields and geomaterials of various origin, for the development of a scientific framework for the application of HPEMP-treatment for directed modification of the structure and properties of mineral, and for solving practical problems aimed primarily at improving of the efficiency of calciferous minerals processing [1 - 4].

The complexity of the flotation separation of calciferous minerals is determined by the similarity of the flotation properties of calcite, fluorite and scheelite. Therefore, increasing the flotation efficiency is an urgent technological task.

Traditionally, the collector for scheelite is technical oleic acid. Flotation is carried out in an alkaline medium with the addition of a depressantliquid glass, which has a slight selective effect. Traditionally, to refine rough scheelite concentrates, a Petrov' method is used, in world practice. The final concentration of scheelite concentrates according to the Petrov' method is an effective, but expensive way. The method consists in processing a rough concentrate at a temperature of $85-90^{\circ} \mathrm{C}$ with a $2-4 \%$ solution of water glass, which provides hydrophilization and depression of calcite and fluorite [5].

It has been shown that it is possible to increase the efficiency of main scheelite flotation by using synthetic collectors of stable composition of alphasubstituted chlorocarbonic or alpha-branched carboxylic acids [6,7]. Nevertheless, studies to increase the contrast of flotation properties of calcium minerals through a combination of collectors continue to be conducted. It is proposed to use a mixture of a complexing collector of hydroxamate and sodium oleate in a ratio of 1 to 2 ,

\#Corresponding author: ryzanceva@mail.ru

doi: 10.5937/JMMA1901045C 
the pulp pH is $8.3[8,9]$.

In the flotation of scheelite ores, liquid glass with module 2 is used as the main depressor of rock minerals. Liquid glass micelles or chains of silicon-oxygen tetrahedrons are able to neutralize the hydrophobizing effect of the collector. The depressing effect of water glass can be powered by combining with polyvalent metals salts or addition of oxalic acid. Another important group of inorganic depressants for scheelite-containing ores are polyphosphates derived from carbohydrates, such as starch, dextrin, carboxymethyl cellulose.

This paper presents the findings of a study of the effects of high-power electromagnetic pulses (HPEMP) parameters on the structural and chemical state of the surfaces of calcite, fluorite, and scheelite and their sorption and flotation properties.

\section{Materials and methods}

In this study, natural calciferous minerals were used - calcite $\left(\mathrm{CaCO}_{3}>98 \%\right)$, scheelite $\left(\mathrm{CaWO}_{4}>\right.$ $98 \%)$, and fluorite $\left(\mathrm{CaF}_{2}>98 \%\right)$, size fraction - 80 $+50 \mu \mathrm{m}$. Distilled water $\left(\mathrm{MeS} / \mathrm{H}_{2} \mathrm{O}=10 / 1\right)$ was added to the samples before they were treated with high-power electromagnetic pulses (HPEMPtreatment).

HPEMP-treatment of the samples was performed on a lab scale in air by a series of pulses between 5 to $10 \mathrm{~ns}$ long. The electrical field component was $30 \mathrm{kV}$ with a pulse frequency of $100 \mathrm{~Hz}$. The pulse energy was approximately $0.1 \mathrm{~J}$ and the integral treatment pulse number varied from $5 \times 10^{2}$ to $1.5 \times 10^{4}$ pulses. Pulse parameters were kept constant and the number of pulses was controlled by varying the treatment duration between $5 \mathrm{~s}$ and $150 \mathrm{~s}$.

The microhardness of minerals before and after electromagnetic treatment was determined by the Vickers method (HV, MPa) according to GOST2999-75 (ISO 6507-1: 2005) on polished sections using a PMT-3M microhardness meter (LOMO, Russia); the impact on indenter is $100 \mathrm{~g}$, loading time $10-15 \mathrm{~s}$.

To identify and study the acid - base properties of the mineral surfaces, the Hammett indicator adsorption method from aqueous media was adopted [10].

The adsorption of oleate was determined using UV spectroscopy according to the residual concentration of oleate ion in the pulp filtrate after contact of the mineral sample with the reagent solution (SU 1322130). Sorption of sodium silicate was determined by the residual concentration of silicon $\left(\mathrm{C}_{\mathrm{si}}\right)$ in the pulp filtrate by the method (PND 14.1.: 2.215 - 06), based on the interaction of silicic acid with ammonium molybdate in an acidic medium.

Flotation test conditions: monomineral sample fraction $\left(\mathrm{CaCO}_{3}, \mathrm{CaF}_{2}, \mathrm{CaWO}_{4}\right)$ sized - $80+50$ $\mu \mathrm{m}, 1.00 \mathrm{~g} ; \mathrm{pH}=10.0$; contact time of the mineral with water $(\mathrm{S}: \mathrm{L}=1: 6) 1 \mathrm{~min}$, with sodium silicate $(100 \mathrm{~g} / \mathrm{t}) 3 \mathrm{~min}$, sodium oleate $(300 \mathrm{~g} / \mathrm{t}) 3 \mathrm{~min}$, flotation time - $1.5 \mathrm{~min}$. Reagent treatment was defined to achieve the highest possible recovery in the flotation of untreated scheelite sample.

\section{Results and discussion}

Micromechanical studies have shown a monotonic decrease in microhardness ( $\mathrm{HV}, \mathrm{MPa}$ ) of mineral samples with an increasing of the treatment times $(10-150 \mathrm{~s})$. The maximum relative drop in microhardness was determiner for treatment during $150 \mathrm{~s}\left(1.5 \times 10^{4}\right.$ pulses $)$ and it was about $66 \%$ for calcite (from $790 \mathrm{MPa}$ to 265 $\mathrm{MPa}$ ), for fluorite it is $53 \%$ (from $912 \mathrm{MPa}$ to 410 $\mathrm{MPa}$ ), for scheelite 49\% (from $2087 \mathrm{MPa}$ to 1017 $\mathrm{MPa}$ ) (Figure 1).

Acid-base properties of the surface: As seen in Figure $2 \mathrm{a}$, the surface of calcite $\left(\mathrm{CaCO}_{3}\right)$ in the native state is mainly composed of Broensted acidic sites (BAS) with $\mathrm{pKa}=1.3\left(55.4 \times 10^{-3}\right.$ $\mu \mathrm{mol} / \mathrm{g})$; neutral sites $\left(\mathrm{pKa}=7.3, \mathrm{n}=15.4 \times 10^{-3}\right.$ $\mu \mathrm{mol} / \mathrm{g})$, base Lewis $\left(\mathrm{pKa}=-4.4, \mathrm{n}=13.4 \times 10^{-3}\right.$ $\mu \mathrm{mol} / \mathrm{g})$, and Broensted (pKa $=12.8, \mathrm{n}=16.6 \times 10^{-3}$ $\mu \mathrm{mol} / \mathrm{g}$ ) sites also constitute a major share. The number of sites with $\mathrm{pKa}=4.1$ and $\mathrm{pKa}=6.4$ is 0.5 $\times 10^{-3}$ and $3.3 \times 10^{-3} \mu \mathrm{mol} / \mathrm{g}$, respectively.

As a result of HPEMP-treatment of the duration $t_{\text {treatment }} \sim 10-30 \mathrm{~s}\left(\mathrm{~N} \sim 10^{3}-3 \times 10^{3}\right.$ pulses $), a$ 
reduction was identified in Broensted base sites from $19.3 \times 10^{-3}$ to $2.8 \times 10^{-3} \mu \mathrm{mol} / \mathrm{g}$, an increase in the concentration of a protonic electron donor Lewis sites with $\mathrm{pKa}=-4.4$ by $\sim 1.2$ times (from
$13.4 \times 10^{-3} \mu \mathrm{mol} / \mathrm{g}$ to $\left.16.7 \times 10^{-3} \mu \mathrm{mol} / \mathrm{g}\right)$ and proton donor Broensted sites with $\mathrm{pKa}=1.3$ and $\mathrm{pKa}=4.1$ by $\sim 1.2$ and $5.2-8.6$ times, respectively.

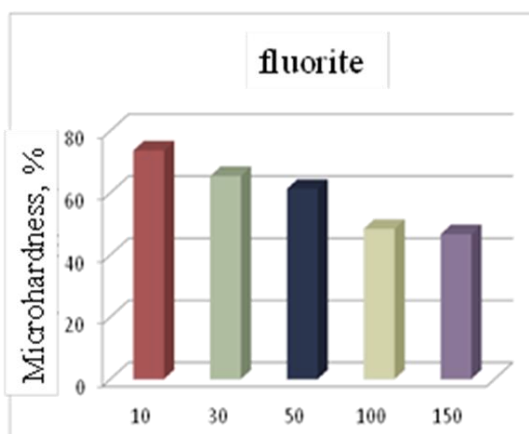

The duration of the treatment, $s$

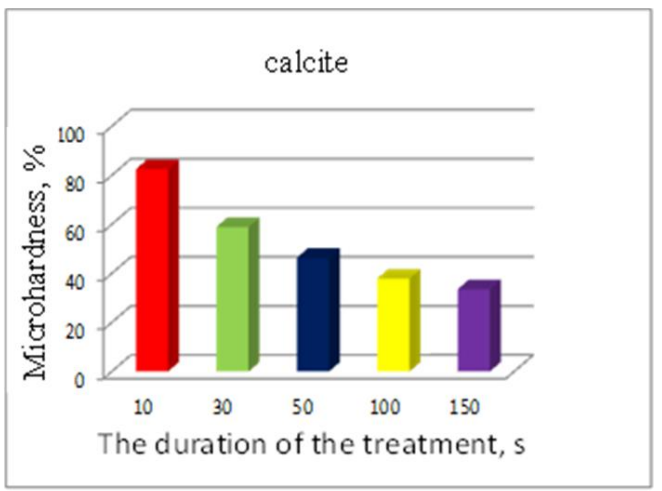

Figure 1. The influence of the HPEMP-treatment on the microhardness (HV, MPa) of mineral samples

Increasing the treatment duration to treatment $\geq$ $50 \mathrm{~s}\left(\mathrm{~N} \geq 5 \times 10^{3}\right)$ resulted in a consistent increase in the number of Broensted base sites with $\mathrm{pKa}=12.8$ by a factor of $10-19.5$ (surface hydroxylation) and a decrease in the number of Lewis base (pKa $=-4.4$ ) and Broensted acid sites with $\mathrm{pKa}=1.3$ and 4.1 (Fig. 2b). Concentration of neutral sites (pKa $=7.3$ and $\mathrm{pKa}=6.4$ ) did not change during the treatment.
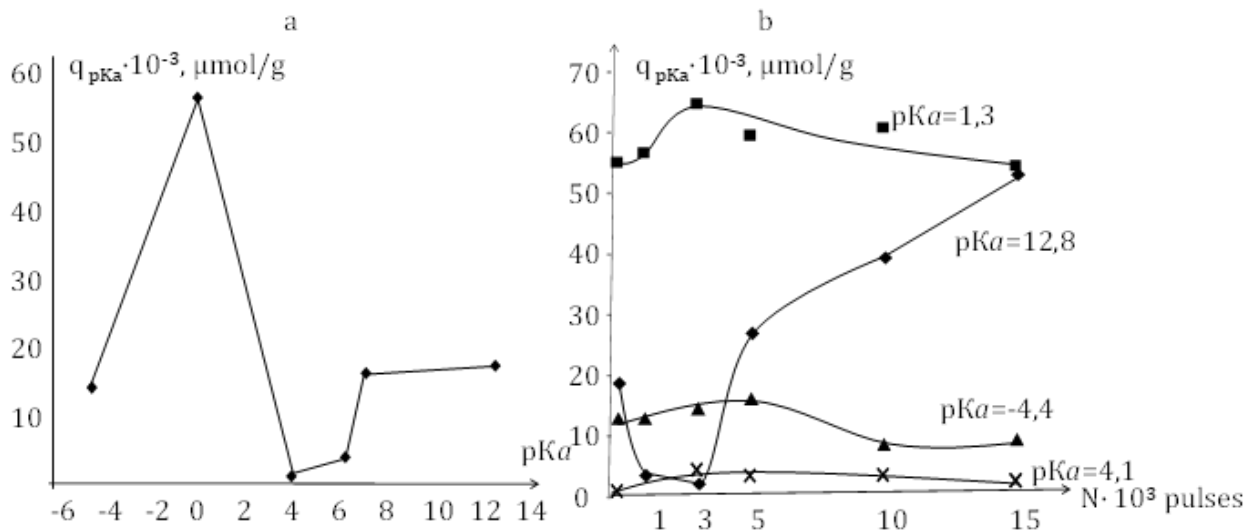

Figure 2. The distribution of the adsorption centers throughout the pKa values for the initial calcite sample (a); the dependence of the active centers with $\mathrm{pKa}=-4.4 ; 1.3 ; 4.1 ; 12.8$ on the number of pulses (b)

Analysis of the calcite data reveals two key findings. The first one is the antibate change in the concentration $(\mu \mathrm{mol} / \mathrm{g})$ of sites with $\mathrm{pKa}=12.8$ and $\mathrm{pKa}=1.3$ depending on the duration of the pulse treatment, which may be interpreted as the conversion of Broensted base and acid sites indicating a change in the donor-acceptor equilibrium and stronger acceptor properties of the surface at $t_{\text {treatment }} \leq 30 \mathrm{~s}$ ( $3 \times 10^{3}$ pulses), followed by weakening with increasing treatment time. The second one is that the increase in the number of sites with $\mathrm{pKa}=4.1$ and $\mathrm{pKa}=-4.4$ may be the 
result of accumulation and annihilation of structural defects.

Distribution of the adsorption sites on the original sample surface of fluorite $\left(\mathrm{CaF}_{2}\right)$ is shown in Figure 3a. The original mineral surface is dominates by Broensted $(\mathrm{pKa}=12.8, \mathrm{n}=195.6 \mathrm{x}$ $10^{-3} \mu \mathrm{mol} / \mathrm{g}$ ) and Lewis (pKa $=-4.4, \mathrm{n}=79.4 \times 10^{-3}$ $\mu \mathrm{mol} / \mathrm{g}$ ) base sites. Besides, Broensted acid (pKa $=4.1, \mathrm{n}=48.2 \times 10^{-3} \mu \mathrm{mol} / \mathrm{g} ; \mathrm{pKa}=1.3, \mathrm{n}=21.9 \mathrm{x}$ $10^{-3} \mu \mathrm{mol} / \mathrm{g}$ ), neutral, and base (pKa $=7.3, \mathrm{n}=$ $\left.0.79 \times 10^{-3} \mu \mathrm{mol} / \mathrm{g}, \mathrm{pKa}=8.8, \mathrm{n}=0.87 \times 10^{-3}\right)$ sites have been identified.

As can be seen in Figure 3, treatment of the mineral for ttreatment $\sim 10 \mathrm{~s}\left(\mathrm{~N} \sim 10^{3}\right)$ reduced the number of sites with $\mathrm{pKa}=-4.4$ by more than an order of magnitude (from $83.21 \times 10^{-3} \mu \mathrm{mol} / \mathrm{g}$ to $8.19 \times 10^{-3} \mu \mathrm{mol} / \mathrm{g}$ ) and increased the number of sites with $\mathrm{pKa}=1.3$ (from $21.9 \times 10^{-3} \mu \mathrm{mol} / \mathrm{g}$ to $118.59 \times 10^{-3} \mu \mathrm{mol} / \mathrm{g}$ ) and 4.1 (from $48.2 \times 10^{-3}$ $\mu \mathrm{mol} / \mathrm{g}$ to $58.2 \mu \mathrm{mol} / \mathrm{g}$ ), i.e. by $\sim 5.5$ and 1.2 times, respectively.

Further increase in the duration of pulse treatment to treatment $\sim 30 \mathrm{~s}$ had the opposite effect, resulting in a significant increase in the sites with $\mathrm{pKa}=-4.4$ and a decrease in the sites with $\mathrm{pKa}=$
1.3; after the treatment, the concentration of the sites with $\mathrm{pKa}=-4.4$ was nearly three times that in the original sample surface.

HPEMP-treatment for 50 seconds $\left(5 \times 10^{3}\right.$ pulses) resulted in a decrease by a factor of at least 11 in the concentration of base sites with $\mathrm{pKa}$ $=-4.4$. Importantly, the increase in Broensted acid sites with $\mathrm{pKa}=1.3$ was not proportional (from $87.57 \times 10^{-3} \mu \mathrm{mol} / \mathrm{g}$ to $96.10 \times 10^{-3} \mu \mathrm{mol} / \mathrm{g}$ ); sites with $\mathrm{pKa}=4.1$, to the contrary, decreased by a factor of 1.2 and the concentration of sites with $\mathrm{pKa}$ $=7.3,8.8$, and 12.8 did not change over the entire examined range of HPEMP values.

Based on the data from the fluorite samples, one can conclude that HPEMP-treatment over $10 \mathrm{~s}$ $\left(10^{3}\right.$ pulses) results in a decrease of Lewis basicity with the conversion of Lewis base sites ( $\mathrm{pKa}=$ 4.4) to Broensted acid sites (pKa $=4.1$ and 1.3), which indicates stronger electron-donor properties of the surface. At $t_{\text {treatment }} \sim 30 \mathrm{~s}$, an explosive growth in Lewis base sites combined with a parallel decrease in Broensted acidity were observed, which apparently is a result of both defect formation and deprotonation and $/$ or dehydroxylation of the sites with $\mathrm{pKa}=4.1$ and 1.3.

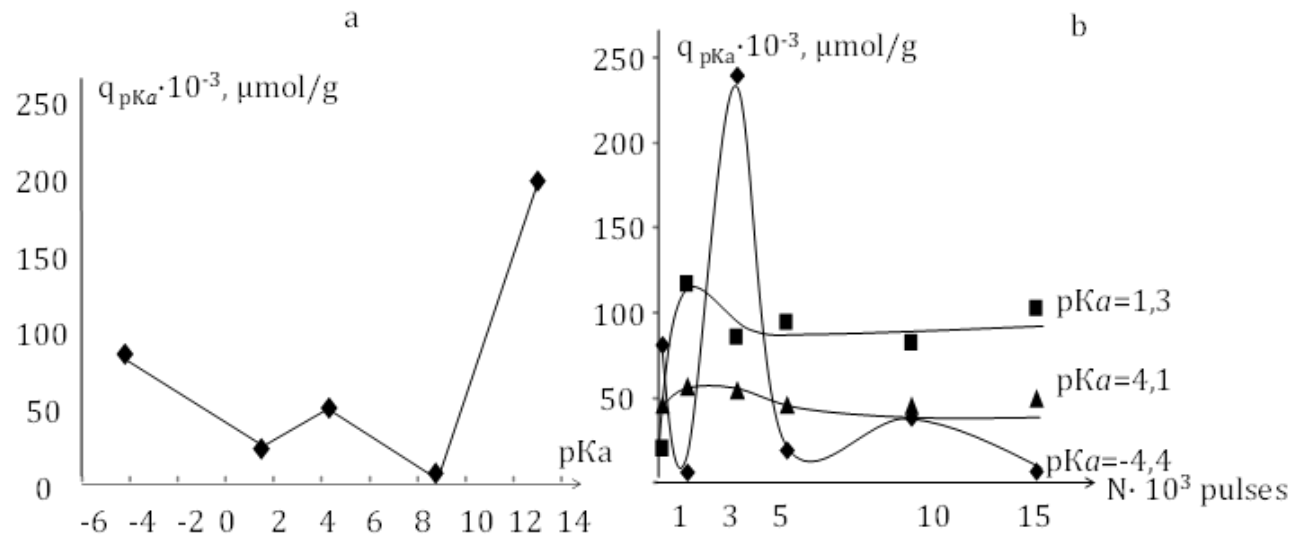

Figure 3. The distribution of the adsorption centers throughout the pKa values for the initial fluorite sample (a); the dependence of the active centers with $\mathrm{pKa}=-4.4 ; 1.3 ; 4.1$ on the number of pulses (b)

Considering the ambiguity of the accumulation mechanism of Lewis base sites (deprotonation indicates stronger acceptor properties, while dehydroxylation indicates the opposite), the effects of this treatment stage on the donor and acceptor properties cannot be conclusively identified. 
However, increasing the treatment time to 50 seconds caused a sharp decrease in the number of Lewis base sites with a minor share converting to proton donor Broensted sites; the latter indicates some increase in the donor ability of the mineral surface.

The surface of the original sample of scheelite $\mathrm{CaWO}_{4}$ is mainly composed of proton donor Broensted sites with $\mathrm{pKa}=1.3\left(\mathrm{n}=45.72 \times 10^{-3}\right.$ $\mu \mathrm{mol} / \mathrm{g}$ ), with $13.16 \times 10^{-3} \mu \mathrm{mol} / \mathrm{g}$ and $19.82 \times 10^{-3}$ $\mu \mathrm{mol} / \mathrm{g}$ sites with $\mathrm{pKa}=4.1$ and 6.4 , respectively. The concentration of Lewis (pKa $=-4.4$ ) and Broensted base sites is not that high: $3.33 \times 10^{-3}$ $\mu \mathrm{mol} / \mathrm{g}$ and $5.52 \times 10^{-3} \mu \mathrm{mol} / \mathrm{g}$, respectively (Fig. 4a).

Using the indicator method, it was demonstrated that the concentration of acid sites with $\mathrm{pKa}=1.3,6.4,7.3$ and $\mathrm{pKa}=8.8$ did not change as a result of the HPEMP-treatment. At the same time, the number of Broensted base sites with $\mathrm{pKa}=12.8$ increased by a factor of $4.8-6$ (from $5.5 \times 10^{-3} \mu \mathrm{mol} / \mathrm{g}$ in the initial surface to $33.11 \times 10^{-3} \mu \mathrm{mol} / \mathrm{g}$ as a result of the HPEMP- treatment of $t_{t r} \sim 150 \mathrm{~s}$ ). However, at $t_{\mathrm{tr}} \leq 100 \mathrm{~s}$, there is a decrease in the number of proton donor Broensted sites with pKa $=4.1$ (Figure 4b), resulting in an increased number of Lewis base sites and the concentration of proton donor Broensted sites falling from $13.16 \times 10^{-3} \mu \mathrm{mol} / \mathrm{g}$ in the original sample to $6.07 \times 10^{-3} \mu \mathrm{mol} / \mathrm{g}$ in the sample after tireatment $\sim 100 \mathrm{~s}$.

In other words, in scheelite, the main changes in the acid and base surface properties are associated with the increase in the number of Broensted alkaline sites.

Considering the fact that the concentration of acid and neutral (pKa $=1.3,6.4,7.3,8.8$ ) sites does not change, the increase in Broensted basicity may be logically explained by the stronger acceptor properties of the surface activation of sites with $\mathrm{pKa} \geq 14$ accompanied by dissociative adsorption of water leading to growth in the number of sites with $\mathrm{pKa}=12.8$. The conversion of sites with $\mathrm{pKa}=-4.4$ to sites with $\mathrm{pKa}=4.1$ indicates weaker donor properties of the surface.

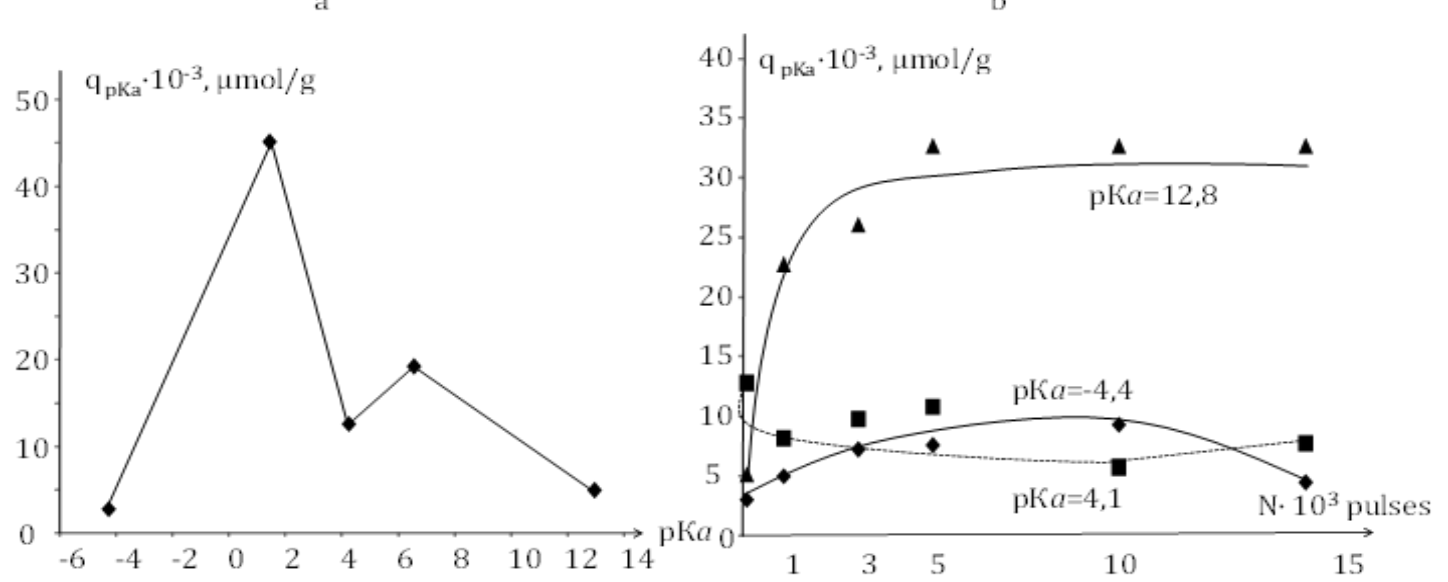

Figure 4. The distribution of the adsorption centers throughout the pKa values for the initial scheelite sample (a); the dependence of the active centers with $\mathrm{pKa}=-4.4 ; 1.3 ; 4.1$ on the number of pulses (b)

The sorption activity of calcium minerals towards oleate was investigated by UVspectroscopy based on the residual concentration of oleic acid in the pulp after the contact of the mineral with the reagent solution. The obtained dates are presented in Figure 5, as it can be seen the preliminary HPEMP-treatment activated the sorption of the collector on the surface of calciferous minerals.

For scheelite samples HPEMP-treatment results to the increasing of the adsorbed oleate quantity $(\mu \mathrm{g} / \mathrm{g})$ by a factor of $1.2-1.3$ times: from 
$139 \mu \mathrm{g} / \mathrm{g}$ (the mineral in the initial state) to 173 $185 \mu \mathrm{g} / \mathrm{g}$ (the sample after the HPEMP-treatment, $\left.\mathrm{N}_{\text {pules }}=3 \times 10^{3}-10^{4}\right)$. For fluorite and calcite, the increasing of the adsorbed reagent quantity is 10 $17 \%$ : the reagent adsorption for fluorite increased from $209 \mu \mathrm{g} / \mathrm{g}$ (initial state) to $238-244 \mu \mathrm{g} / \mathrm{g}$ $\left(\mathrm{N}_{\text {pules }}=3 \times 10^{3}-10^{4}\right)$. For calcite samples, the rising of the sorption quantity was about $15 \%$ : from $229 \mu \mathrm{g} / \mathrm{g}$ (initial sample) to $260-269 \mu \mathrm{g} / \mathrm{g}$ for the mineral after HPEMP-treatment $\left(\mathrm{N}_{\text {pules }}=3 \times 10^{3}-10^{4}\right)$.
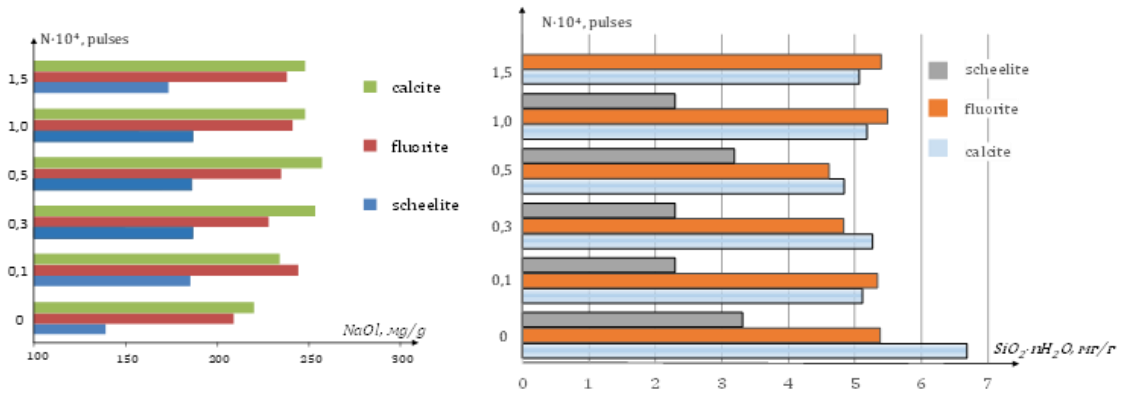

Figure 5. The influence of HPEMP-treatment (Nimp. $\left.=10^{3}-1.5 \times 10^{4}\right)$ on the quantity $(\mathrm{mg} / \mathrm{g})$ of oleic acid adsorbed on the surface of calcite, fluorite and scheelite (a); the influence of the HPEMP-treatment on the sodium silicate sorption on the surface of scheelite, fluorite and calcite (b).

The study of the HPEMP-treatment influence on adsorption of sodium silicate at the minerals surface demonstrates the decreasing in the quantity $(\mathrm{mg} / \mathrm{g})$ of the adsorbed reagent by 10 $25 \%$ (Figure 5). In the case of scheelite and fluorite, the decreasing in the amount of adsorbed sodium silicate quantity was $10-14 \%$ : for scheelite - $3.2 \mathrm{mg} / \mathrm{g}$ (mineral in the initial state), 2.1 - 2.2 $\mathrm{mg} / \mathrm{g}$ for samples after the HPEMP-treatment $\left(N_{\text {pulses }}=10^{3}-3 \times 10^{3}\right)$. The influence is more effective for calcite: the decreasing in the quantity of adsorbed sodium silicate was $\sim 20-25 \%$ as compared to the sample in the initial state $(6.7$ $\mathrm{mg} / \mathrm{g}$ ) and $4.8-5.1 \mathrm{mg} / \mathrm{g}$ for the sample after the HPEMP-treatment $\left(\mathrm{N}_{\text {pulses }}=(3-5) \times 10^{3}\right)$.

Flotation test results: Figure 6 illustrates the relationship between the floatability of monomineral fractions of calcite, fluorite, and scheelite and the duration of HPEMPtreatment.
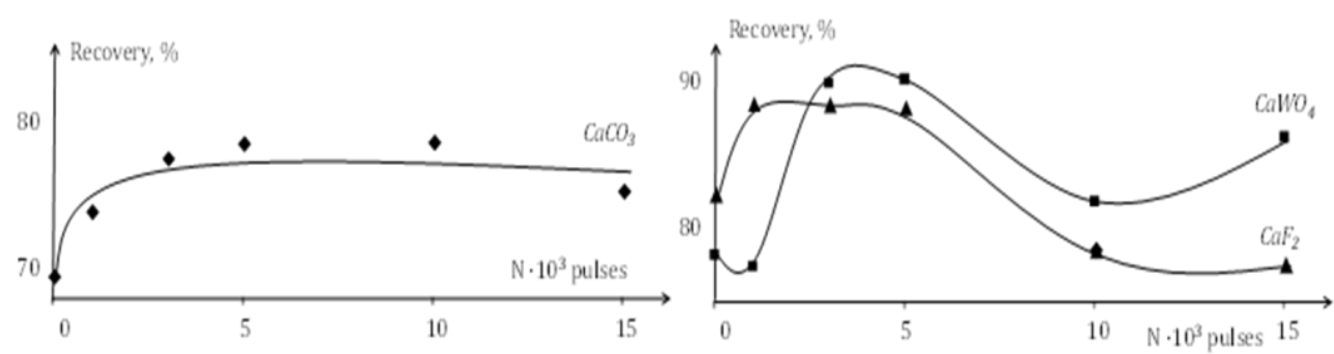

Figure 6. Floatability of calcite, fluorite and scheelite as function of the number of pulses

It can be seen that, in the studied minerals, there is an increase in the froth yield as a result of a short ( $t_{t r} \leq 50 \mathrm{~s}$ ) HPEMP-treatment - the largest increase in recovery achieved was $8 \%$ in calcite, $6 \%$ in fluorite, $12 \%$ in scheelite.
To confirm the obtained effect, using the above parameters of HPEMP, flotation experiments were carried out with a mixture of pure minerals weighing $3 \mathrm{~g}$, with a ratio of calcite : fluorite : scheelite $=1: 1: 1$. 
The obtained results showed that preliminary electromagnetic treatment (HPEMP-treatment) of the artificial mixture allows to increase recovery of tungsten in concentrate. It was experimentally determined that with the consumption of sodium oleate $200 \mathrm{~g} / \mathrm{t}$ and sodium silicate $100 \mathrm{~g} / \mathrm{t}$, the rising in the $\mathrm{W}$ recovery is $6.1-7.2 \%: 44.4 \%(0$ imp is the reference sample), $51.5 \%$ (3000 pulses) and $50.6 \%$ (5000 pulses), the content of W in the concentrate, at the same time, increases by 1.9 $2.5 \%$. An increase in the consumption of sodium oleate to $250 \mathrm{~g} / \mathrm{t}$ eliminates the effect of electromagnetic pulsed exposure: $W$ extraction increases by $3.0-3.3 \%$ from $95.5 \%$ ( $0 \mathrm{imp}$ ) to 98.5 - 98.8\% (3000 imp and 5000 imps, respectively), and the quality (W content) of the concentrate is improved by $1.5-2.0 \%$.

As applied to selectivity increasing of the flotation separation of calcite from fluorite under monomineral flotation conditions (consumption of sodium oleate - $100 \mathrm{~g} / \mathrm{t}$, aluminum sulfate and sodium silicate $-500 \mathrm{~g} / \mathrm{t}$ ) the possibility of the minerals selectivity separation was determined because of fluorite activation on $12-14 \%$ at $10 x$ $10^{4}$ pulses.

Thus, it can be concluded that as a result of the research conducted, the principal possibility of using pulsed energy effects to increase the efficiency of the flotation process of calciumcontaining minerals has been experimentally substantiated.

\section{Conclusion}

1. Using the Hammett color indicator adsorption method, following key evolution mechanisms were identified of the acid-base sites in calcium mineral surfaces exposed to high-voltage nanosecond pulses: stronger electron-donor properties of fluorite surfaces and stronger acceptor properties of scheelite surfaces as a result of HPEMPtreatment; mutual conversion at $t_{o b r} \leq 30 \mathrm{~s}$ of Broensted base and acid sites in calcite surfaces resulting in weaker donor properties and stronger acceptor properties of the mineral surfaces, and then, at $t_{o b r}>30 \mathrm{~s}$, recovery (strengthening) of the donor properties of the surfaces.

2. It was determined that HPEMP-treatment of calciferous minerals causes the increasing in their sorption activity towards a fatty acid collector (sodium oleate) and a decrease in the quantity $(\mathrm{mg} / \mathrm{g})$ of adsorbed depressor (sodium silicate). The increasing of adsorbed sodium oleate quantity for scheelite was 20 - 30\% as compared with the initial sample; for calcite and fluorite, the increasing of the adsorbed reagent quantity was about 10 $20 \%$. The decreasing in the quantity of adsorbed sodium silicate $(\mathrm{mg} / \mathrm{g})$ was $10-15 \%$ for scheelite and fluorite and $20-25 \%$ for calcite.

3. In monomineral flotation of calcite, fluorite, and scheelite, the optimal parameters of the HPEMP-treatment were identified (trreatment $~ 10$ $50 \mathrm{~s})$ and the reagent treatment was optimized for scheelite recovery, resulting in an increase of recovery of $8 \%$ in calcite, $6 \%$ in fluorite, and 10 $12 \%$ in scheelite.

\section{Note}

A part of this study was presented at the XIII International Mineral Processing and Recycling Conference, organized by the University of Belgrade, Technical Faculty in Bor, from $8 t^{\text {h }}$ to $10 t^{\text {th }}$ May 2019, Belgrade, Serbia.

\section{References}

[1] Chanturia, V.A., Bunin, I.Z., Ryazantseva, M.V., Khabarova, I.A. (2012) Influence of nanosecond electromagnetic pulses on phase surface composition, electrochemical, sorption and flotation properties of chalcopyrite and sphalerite. Journal of Mining Science, 48 (4), 732-740.

[2] Chanturia, V.A., Bunin, I.Z., Ryazantseva, M.V., Khabarova, I.A. (2013) X-Ray photoelectron spectroscopy - based analysis of change in the composition and chemical state of atoms on chalcopyrite and sphalerite surface before and after the nanosecond 
electromagnetic pulse treatment. Journal of Mining Science, 49 (3), 489-498.

[3] Chanturia, V.A., Bunin, I.Z., Ryazantseva, M.V., Khabarova, I.A., Koporulina, E.V., Anashkina, N.E. (2014) Surface activation and induced change of physicochemical and process properties of galena by nanosecond electromagnetic pulses. Journal of Mining Science, 50 (3), 573-586.

[4] Ryazantseva, M.V., Bunin, I.Z. (2015) Modifying acid-base surface properties of calcite, fluorite and scheelite under electromagnetic pulse treatment. Journal of Mining Science, 51 (5), 1016-1020.

[5] Yu, Y., Sun, C., Song, Z., Zhag, X. (2014) The mechanism on separation of scheelite and calcium minerals in heating process. In: Proc. Of the XXVII IMPC. Santiago, Chile, 133-143.

[6] Ustinov, I.D, Ryaboy, V.I. Koroleva, E.V.
Petrova, L.N. (1995) Improving the technology of flotation of molybdenum - scheelite ores with use of new collectors. In: Processing of oxidized ores (Nauka), Moscow, 22-25.

[7] Ryaboy, V.I. (1995) Development of works on flotation regents at the "Mekhanobr" Institute. Obogashenie Rud, (1-2), 116-121.

[8] Gao, Y., Gao, Z., Sun, W., Hu, Y. (2016) Selective flotation of scheelite from calcite: $A$ novel reagent scheme. International Journal of Mineral Processing, 154, 10-15.

[9] Gao, Z., Bai, D., Sun, W., Cao, X., Hu, Y. (2015) Selective flotation of scheelite from calcite and fluorite using a collector mixture. Minerals Engineering, 72, 23-26.

[10] Nechiporenko, A.P. et. al. (1985) Indicative method of the solid surface acidity investigation. Russian journal of general chemistry, 9, 1907-1912.

\title{
UTICAJ ELEKTROMAGNETNIH PULSEVA VELIKE SNAGE NA STANJE POVRŠINE I TEHNOLOŠKE KARAKTERISTIKE MINERALA GVOŽĐEVITOG KREČNJAKA
}

\author{
V.A. Chanturiya' ${ }^{1}$ I.Zh. Bunin¹, M.V. Ryazantseva"\# \\ 1Institute of Comprehensive Exploitation of Mineral Resources Russian Academy of Sciences \\ named after academician N.V. Mel'nikov, Moscow, Russia
}

(Primljen: 30. Septembar 2019.; Prihvaćen: 14. Novembar 2019.)

\begin{abstract}
Izvod
U ovom radu je ispitivana promena strukturnih hemijskih osobina prirodnog fluorita, šelita $i$ kalcita pod uticajem elektromagnetnih pulseva velike snage (HPEMP postupak) na osnovu adsorpcije kiselo-baznih indikatora. Utvrđeno je da tokom HPEMP postupka u periodu od 30 sekundi $\left(3 \times 10^{3}\right.$ pulseva) dolazi do povećanja sposobnosti doniranja elektrona na površini fluorita, kao i do povećanja akceptorskih svojstva na površini kalcita i šelita.

Flotacijski testovi potvrdili su da postupak elektromagnetnim pulsevima velike snage omogućava poboljšanje flotabilnosti minerala gvožđevitog krečnjaka. Povećanje iskorišćenja šelita iznosilo je 10-12\%, fluorita 5-6\%, a iskorišćenje kalcita povećalo se za $7-8 \%$.
\end{abstract}

Ključne reči: Kalcit; Fluorit; Šelit; Flotabilnost; Elektromagnetni pulsevi velike snage. 